\title{
Developing Pop-Up Book Learning Media to Improve Cognitive Ability of Children Aged 4-5 Years
}

\author{
Dian Idha Rahmawati, Rukiyati \\ Universitas Negeri Yogyakarta, Yogyakart, Indonesia \\ e-mail: dian.idha2016@student.uny.ac.id
}

\begin{abstract}
This study aims: (1) to develop pop-up book learning media appropriate for children aged 4-5 years and (2) know the effectiveness of pop-up book learning media to improve cognitive ability for children aged 4-5 years. This development research adopted Borg \& Gall. The subjects used for the preliminary field test were 2 teachers and 12 children aged 4-5 years and main field test of 4 teachers and 31 children aged 4-5 years. The operational field test consisted of 40 children. Techniques and instruments of data collection were conducted through interviews, validation sheets, teacher and child response questionnaires, and observation sheets. Data collection techniques on operational trial used one-group pretest-posttest design. Data analysis used homogeneity test, normality test, paired sample t-test with significance level 0.05 . The results show that: (1) The research has successfully developed a pop-up book learning media for children aged 4-5 years, (2) pop-up book learning media was appropriate to be used according to expert judgment and test result, and (3) the media of pop-up book was effective to improve cognitive ability for children aged 4-5 years. This can be seen from the result of paired sample t-test calculations in which the significance value was 0.00 less than $0.05(<0.05)$, meaning that the pop-up book learning media was effective to improve cognitive ability for children aged $4-5$ years.
\end{abstract}

Keywords: learning media, pop-up book, cognitive development

\section{INTRODUCTION}

Indonesia has experienced a crisis in various fields such as in the handle of education, economics, social and culture. These various crises appear along with the development of contemporary times. One crisis in Indonesia should get more attention is in education. Education has a strong impact on the development of a country. Education is important to develop students in the life. One problem is Indonesian students could not compete with other countries' students. So Indonesian education must be able to prepare graduates able to overcome the competition. One ability has an important role and needs to improve is cognitive abilities because they have important implications for interpersonal behavior and relationships (Murphy \& Hall, 2011). Cognitive development in the domain of mathematics is very important for educational and financial success in contemporary society. (National Mathematics Advisory Panel, 2008).

Based on the results of data from the 2015 Trends in International Mathematics and Science Study (TIMSS) conducted on elementary school students showing the achieved of Indonesian students in mathematics ranked 46 of 51 countries with a score of 397 . The average percentage of correct answers in the cognitive domain of children in Indonesia got a score of 76 while the average for international children is 150 . The average percentage of correct answers in the domain of number and geometry content in Indonesia is 24 and 28 while for international scores 49 and 50. This shows that children's mathematical abilities in numbers and geometry still low compared to other countries. According to the survey they ability low because 
there were still many children who had not attended early childhood education. From the data got $28 \%$ of students in Indonesia not attending early childhood education, this the fifth largest number compared to other countries. Another reason is the lack of stimulation given to children, $27 \%$ of parents in Indonesia do activities that stimulate numeracy and literacy skills of students, such as reading fairy tales, singing the alphabet (Litbang.kemdikbud.go.id). Based on the findings, the spread of early childhood education institutions and cognitive stimulation at an early age influence the next level of education. Merkley \& Ansari (2016: 20) which shows that cognitive development which highlights knowledge of number symbols is a longitudinal predictor of mathematical achievement. This knowledge mediates the transition between informal and formal mathematics learning and can improve school readiness.

Based on the six longitudinal datasets found that mathematical skills in terms of numbers can predict the performance at the next school level higher than early reading skills, attentional skills or social-emotional skills. (Duncan, Dowsett, Claessens, Magnuson, Huston, Klebanov, Pagani, Feinstein, Engel, Brooks, Sexton, Duckworth, Japel, 2007: 1443). In fact, they were to leave this potential unrealized for many children. To realize this, a mathematical intervention needed providing experience for early childhood so children's mathematical knowledge increases. There are advantages to involving children in the mathematical experience, the knowledge of preschoolers about mathematics can use to predict success at the level of education in elementary schools and even high schools (Clements \& Sarama, 2011: 968).

Seeing these conditions required special attention so as not to cause a worse impact in the following year. Observed from the consequences of early childhood, early childhood cognitive abilities of early mathematics need to develop. Early childhood cognitive abilities can improve from providing stimulation through media suitable for children according to the characteristics and needs of children. Piotrowski \& Valkenburg (2015: 1783) stated that media and child development had a greater effect. In this study, the authors developed pop-up books for stimulating children's cognitive media.

Pop-up books are different from books in general because they have dimensions when the book is opened so that it adds enthusiasm, with pop- up books the teacher can invite student interactivity in its use, students can use individually or in groups (Hiner, 2006: 19). Iizuka (2011: 605), states that Pop-Up is a paper craft with an attractive and consistent shape on the folds of paper shaped into 3 dimensions when opened. Furthermore, Dzuanda (2011: 5-6) showed that pop-up books can develop children's creativity, stimulate children's imagination, increase knowledge and give an introduction to objects, and can a medium to foster interest in reading in children. In addition, the benefits of reading pop-up books, pop-up methods, empower readers to control the order of time, move forward and back according to their wishes, and the ability to entertain and surprise even through repeated reading, the reader will remember the content by (Boyce, 2011: 254).

The use of books with Pop-up forms contains material about cognitive is expected to make children's cognitive skills in the early mathematics field increase. This is because pop-up books children's skills can be honed, which includes the ability to conceptualize numbers, patterns, and classification. Based on observations and interviews known that the implementation of learning in children is only centered on the teacher and the use of learning media that is less varied. So pop-up books can be an interesting media for children and can be a medium for learning, especially in children's cognitive development. Based on the description of the above problems, it is necessary to develop a book with an interesting form and containing cognitive material close to the child, so that the basic concepts of early mathematics can be studied more optimally and meaningfully by children.

\section{METHOD}

The research method that used is a research and development (R\&D) method that can interpret as a scientific way to research, design, produce and test the validity of products it has produced (Sugiyono, 2015: 30). The Subjects in this study are children aged 4-5 years in Sragen. The subjects used for the preliminary field test were 2 teachers and 12 children aged 4-5 years, the main field test of 4 teachers and 31 children aged 4-5 years, and then in operational field test comprised 40 children.

Techniques and instruments of data collection conducted through interviews, validation sheets, teacher and child response questionnaires, and 
observation sheets, and a test. The validity measured through the media validation sheet, then using the passing grade $(\mathrm{X})$ which was the average score of the assessment results of academic and practitioners validatory and adapted to the media form the assessment criteria that have developed in table 1.

Table 1. Criteria for Validating the Media

\begin{tabular}{cllc}
\hline \hline No & \multicolumn{2}{c}{ Interval } & Category \\
\hline 1 & $\mathrm{X} \geq \mathrm{Xi}+1,5 \mathrm{SBx}$ & $\mathrm{X} \geq 3.25$ & Very Valid \\
2 & $\mathrm{Xi}+1,5 \mathrm{SBx}>\mathrm{X} \geq \mathrm{Xi}$ & $3.25>\mathrm{X} \geq 2.5$ & Valid \\
3 & $\mathrm{Xi}>\mathrm{X}>\mathrm{Xi}-1,5 \mathrm{SBx}$ & $2.5>\mathrm{X} \geq 1.75$ & Low valid \\
4 & $\mathrm{X}<\mathrm{Xi}-1,5 \mathrm{SBx}$ & $\mathrm{X}<1.75$ & Invalid \\
\hline \hline
\end{tabular}

(Modification Mardapi, 2012:162)

Data in the form of observations of observations of children's responses using the agreement criteria in the form of total score assessment data with the assessment instrument model "yes, will not be processed using the percentage of an agreement formula (Grinnell, 1998,160).

$$
\% \text { of agreements }=\frac{\text { Agree }}{\text { Disagree }+ \text { agree }} \times 100
$$

The effectiveness of pop-up book media measured using students' learning outcomes. To decide the effectiveness of the pop-up book media, it was necessary to conduct pretest and posttest. The experimental design using pre-experimental design in the form of one-group pretest-posttest design so that the treatment result can be more exact. This research conducts pretest to decide the students' learning outcomes before using pop-up book media. Then conducts posttest to decide the students' learning outcomes after using pop-up book media.

In addition, used a paired t-test to decide the significance students' learning outcomes improvement on cognitive ability. This research conducted a data analysis technique of paired t-test using Statistical Package for Social Sciences (SPSS) software. Normality testing of the data was to use Kolmogorov Smirnov.

\section{RESULT AND DISCUSSION}

\subsection{Result}

The Development of Pop-up Book Media

Preliminary Study. The development of pop-up book media in this study starts with the preliminary study, planning and developing the product. Preliminary study attends to get the first data and the needs of teachers and children in the teaching and learning process. By conducting a needs analysis, it can develop media pop-up book learning on the conditions and conditions faced by students. In this preliminary study phase, information gathering includes needs analysis and literature study. Based on the needs analysis, it gets general information about the learning it applies that in schools.

In cognitive learning, teachers use more conventional methods such as lectures so that learning is teacher-centered and provides fewer opportunities for children to take part direct and active in the learning process. In addition, the media used in learning is less varied. Teachers often use 2D, LKA or magazine images in the learning process, so that children often bored and are less interested in learning. They seldom use learning media that is more interesting and real. Most of them show that the material in the magazine was coherent, making it easier for teachers to teach. Furthermore, researchers found that most of the cognitive abilities of children have not developed optimally. They still experience difficulties in the numbers concept, organizing number symbols and sorting numbers. The ability to classify objects and pattern recognition of children is still low.

Teacher's knowledge of Pop-up books is still low. Respondents who know about pop-up books are only $30 \%$, the rest they don't know what pop-up books are. Most respondents show they had never used pop-up books in learning. The respondents have only seen pop-up books in the form of storybooks, but have never tried to use them for learning. Furthermore, researchers dig up information about whether pop-up books needed as media for cognitive learning for children. Respondents showed that needed cognitive stimulus media based pop-up book for cognitive learning. These respondents think pop-up books will interest to children. So, children will focus and not bored. In addition, children will focus and not bored. In addition, respondent showed that the media pop-up books will motivate children in learning. 
Planning. In the preparation of the framework hold inside cognitive stimulation media based on Pop-Up Books refers to the results of information gathering in preliminary studies. Steps in planning research and development include: determining the material and indicators according to the stage of child cognitive development in age 4-5 years. It uses literature studies to decide this indicator. The next stage is determining the theme, in this Pop-Up Books, the theme taken for transportation. After it determines the theme, the researcher has a pop-up technique suitable for use the book. The next stage is determining the theme, in this Pop-Up Books, the theme taken for transportation. After it determines the theme, the researcher has a pop-up technique suitable for use the book. The next stage is determining the theme, in this Pop-Up Books, the theme taken for transportation. After it determines the theme, the researcher has a pop-up technique suitable for use the book. The techniques used are Pop-up Pop-ups, v-fold, 45o fold, box fold. Next, the researcher determines the image matches the theme and color suitable for the characteristics of children aged 4-5 years. The final stage of developing popUp Books learning media is the decision of the material to use.

Product Development. At the development stage, the first step in developing the product was compiling cognitive stimulation media material based on Pop-Up Books. Pop-up book material about cognitive abilities divided into 3 series has introduced the concept of numbers, classification and pattern recognition. Of these three materials are more inclined to cognitive development in the early mathematics. The next step after has determined the material is to design an image pattern according to the material that has determined using Corel Draw X5. After it finishes the design, prints the image in Ivory 260 gr paper.

\section{The Feasibility of Pop-Up Book Media}

The finished Pop-Up Book learning media needs to be tested in terms of eligibility through expert validation tests by material experts and media experts, and feasibility tests on Preliminary field testing and main field testing. Material validity in this research is Yogyakarta Postgraduate State University lecturer. The following is the assessment of pop-up book media validation by the material expert.
Table 2. Results of Evaluation of Expert Validation material

\begin{tabular}{|c|c|c|c|}
\hline No & Assessment content & Average & Category \\
\hline 1. & Material content & 3.50 & Very Good \\
\hline 2. & Language & 3.20 & Good \\
\hline \multirow[t]{2}{*}{3.} & Persentasion & 3.20 & Good \\
\hline & Validity & 3.30 & Very Valid \\
\hline
\end{tabular}

Overall, the assessment of material content, language and presentation aspects got a score of 3.30 is included which in the "Very valid" category. So that the product resulting from the development is feasible for use. Besides providing an assessment, material experts give the advice to help improve the learning media of pop-up books. Material experts recommend that the size of the text and images in the pop-up book learning media guide to make it bigger, so it is clearer.

Material validity in this research is Yogyakarta Postgraduate State University lecturer.

Table 3. Results of Media Expert Validation Assessment

\begin{tabular}{llll}
\hline No & Assessment content & Average & Category \\
\hline 1. & Content Quality & 3,57 & Very Good \\
2. & Instructional quality & 3,43 & Very Good \\
3. & Technical Quality & 3,27 & Very Good \\
\hline & Validity & 3,42 & Very Valid \\
\hline \hline
\end{tabular}

Overall assessment of content quality, instructional quality and quality of techniques got a score of 3.42 included in the "Very Good" category. So, material expert declared cognitive stimulation media based on Pop-Up Books feasible for the field. Besides assessing, experts suggested making a cover with contrasting colors and making the corners of the book curved. Media experts suggest creating interesting guides to make it easier for teachers to use cognitive stimulation media based on Pop-Up Books. After the material experts and the media stated that the pop-up book learning media was feasible, then go ahead with the field test.

Preliminary field testing. The first field trial involved 2 teachers and 12 children from Tunas Harapan Tangkil kindergarten in Sragen. Preliminary field testing carried out during 3 meetings to get the suggest from teachers and children's responses to cognitive stimulation media based on pop-up books developed. 
At the first meeting, teachers used cognitive stimulation media based on pop-up books in groups. At the second and third meetings, the teacher provides opportunities for children individually to use the media.

Table 4. Recapitulation of Teacher Respons Results in Preliminary field testing

\begin{tabular}{llcccc}
\hline \hline No & Assessment & \multicolumn{2}{c}{ Teacher's } & & \\
& content & Score & Average & Category \\
& & T 1 & T 2 & & \\
\hline 1. & Material content & 3.27 & 3.36 & 3.32 & Very Good \\
2. & Persentasion & 3.22 & 3.44 & 3.33 & Very Good \\
\hline & Validity & 3.25 & 3.40 & 3.33 & Very Valid \\
\hline \hline
\end{tabular}

Based on material content and presentation aspects get an average score in category "very good" and in the overall assessment, the criteria got are in the "very valid". Besides getting assess from the teacher, researchers got data from children's responses to Pop-Up Books learning media.

Children's response for each item statement is good. They are interested in pop-up books to learn new things in the learning and different from other learning media. It looked interesting affected the learning environment became more enjoyable. Children agreed that learning to use a pop-up book can increase the motivation, and present material was easy. The pictures and material contained on the pop-up book following the theme. Children agreed to use the pop-up book as an alternative media for understanding the cognitive development, even they wished to use a pop-up book for the other content.

Table 5. Recapitulation of children's responses Results in Preliminary field testing

\begin{tabular}{clcc}
\hline \multirow{2}{*}{ No } & \multicolumn{1}{c}{ Item } & \multicolumn{2}{c}{ Child } \\
& & \multicolumn{2}{c}{ Response } \\
& Yes & No \\
\hline 1 & Material in pop-up books is easy to learn & $80 \%$ & $20 \%$ \\
2 & Material in pop-up books attracts & $100 \%$ & $0 \%$ \\
3 & Pop-up books are easy to use & $80 \%$ & $20 \%$ \\
4 & Pop-up book covers good & $90 \%$ & $10 \%$ \\
5 & Colors in pop-up books is good & $80 \%$ & $20 \%$ \\
6 & types and sizes of letters and numbers in & $100 \%$ & $0 \%$ \\
& pop-up books easy to read & $70 \%$ & $30 \%$ \\
7 & Pop-up books last when used & $100 \%$ & $0 \%$ \\
8 & Images in pop-up books are interesting & $90 \%$ & $10 \%$ \\
9 & Pop-up books foster children's interest & $100 \%$ & $0 \%$ \\
10 & Pop-up books foster children's interest & $89 \%$ & $11 \%$ \\
\hline Average Percentage & & \\
\hline \hline
\end{tabular}

The results of the analysis of child response data during cognitive learning activities using cognitive stimulation media based on Pop-Up Books received a percentage of $89 \%$. This means that the pop-up media book is suitable for use for 4-5 years old children.

Revision. The second stage of revision carried out after carrying out the Preliminary field testing by the response from 2 Tunas Harapan Kindergarten teachers and 12 child's age 4-5 years. The results of the second stage product revision are fixing the size of the image in a pop-up.

Main Field Testing. In this main field testing, researchers involved 4 teachers and 31 children aged 4-5 years from 2 schools, Pertiwi Kindergarten and Perwanida Kindergarten. The systematic implementation of this main field testing is the same as systematics in the Preliminary field testing, only involving more respondents.

Table 6. Recapitulation of Teacher Assessment Results in main field testing

\begin{tabular}{cccccccc}
\hline \hline No & Assessment & \multicolumn{9}{c}{ Teacher's Score } & \multirow{2}{*}{ Average } & \multirow{2}{*}{ Category } \\
\hline 1. & Material & T 1 & T 2 & T3 & T 4 & & \\
content & 3.36 & 3.55 & 3.73 & 3.73 & 3.59 & $\begin{array}{c}\text { Very } \\
\text { Good }\end{array}$ \\
2. & Persentasion & 3.44 & 3.56 & 3.67 & 3.78 & 3.61 & $\begin{array}{c}\text { Very } \\
\text { Good }\end{array}$ \\
\hline & Validity & 3.40 & 3.55 & 3.70 & 3.75 & 3.60 & $\begin{array}{c}\text { Very } \\
\text { Valid }\end{array}$ \\
\hline \hline
\end{tabular}

Overall, the teacher's assessment received a good response. The teacher gives a few suggestions to change the color and size of the pop-up book.

Table 7. Recapitulation of the results of children's responses to main field testings

\begin{tabular}{llll}
\hline \multirow{2}{*}{ No } & \multicolumn{1}{c}{ Item } & \multicolumn{2}{c}{ Child Response } \\
& & Yes & \multicolumn{1}{c}{ No } \\
1 & Material in pop-up books is easy to learn & $100 \%$ & $0 \%$ \\
2 & Material in pop-up books attracts & $100 \%$ & $0 \%$ \\
3 & Pop-up books are easy to use & $93.55 \%$ & $6.45 \%$ \\
4 & Pop-up book covers good & $100 \%$ & $0 \%$ \\
5 & Colors in pop-up books is good & $100 \%$ & $0 \%$ \\
6 & types and sizes of letters and numbers & $10 \%$ & $0 \%$ \\
7 & pop-up books easy to read & $100 \%$ & 12.90 \\
& Pop-up books last when used & $87.10 \%$ & $\%$ \\
8 & Images in pop-up books are interesting & $100 \%$ & $0 \%$ \\
9 & Pop-up books foster children's interest & $100 \%$ & $0 \%$ \\
10 & Pop-up books foster children's interest & $100 \%$ & $0 \%$ \\
Average Percentage & $98.06 \%$ & $1.94 \%$ \\
\hline \hline \multicolumn{4}{l}{} \\
\hline
\end{tabular}


Children's response in main field testing is great, they are enthusiastic using pop-up media books. The results of data analysis on the response of children get a percentage of $98 \%$. So, the media feasible for children.

Revision. This third stage revision includes replacing a less bright pop-up book, such as changing the color of a light pink bus to an older pink one. In addition, the teacher gives suggest changing the size of the book that is too large for children, from the first size of $21 \times 52$ to $21 \times 42$.

The Effectiveness of Pop-Up Book Media. Operational field testing.

The media effectiveness test is carried out on operational field testing using pop-up book media. In operational field testing, the effectiveness test carried out for 6 meetings which involved children aged 4-5 years from RA Masyithoh 1 and RA Masyithoh 2 as the experimental class. The experimental design used was One Group Pre-test Post-test Design, where children aged 4-5 years in RA Masyithoh 1 and RA Masyithoh 2 received treatment using cognitive stimulation media based on Pop-Up Books in cognitive learning. The pretest is doing before give the child treatment using the media pop-up book and a posttest after giving the child treatment to see the value of children's cognitive abilities.

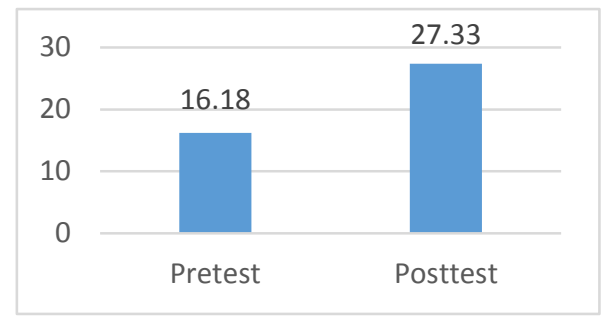

Fig. 1. Comparison Of Pretest And Posttest Values

Table 8. Cognitive abilities Paired Sample t-test Test Results

\begin{tabular}{lrrcc}
\hline & t & & $\begin{array}{c}\text { Sig. (2- } \\
\text { tailed) }\end{array}$ \\
\hline $\begin{array}{l}\text { Pair 1 } \\
\text { Posttest }\end{array}$ & Pretest- & - & & 0,00 \\
\hline
\end{tabular}

Table 8 shows that the results of the pairedsample t-test for cognitive ability before and after using cognitive stimulation media based on Pop-Up
Books got a significance value of $0.000<0.005$ which showed that $\mathrm{Ha}$ was accepted. So, it means that a significant difference between the results of cognitive abilities child's age 4-5 year before using pop-up book media and after using it. With regard to this matter, it can be concluded that the development of pop-up book is effective to improve cognitive abilities of children age 4-5 years.

\subsection{Discussion}

The development of pop-up book learning media began as an effort to give interactive media in cognitive learning. These efforts are intended to make an analysis of whether the proposed material is proper for the level of children aged 4-5 years. This stage of needs analysis presents the first information to decide whether the developed media has promising prospects to develop in the study.

Referring to interviews and further observations of teachers and children, it found that in the classroom more often applying teachercentered learning and not giving children the opportunity to take part directly and actively in the learning process, so that children's participation in learning was lacking. In addition, the media used in learning is less varied so that children often bored and are less interested in learning. They very rarely use learning media that is more interesting and real. Most of them showed that the material in the magazine was coherent, making it easier for teachers to teach. The findings have an influence on the cognitive abilities of children that have not developed optima. They still experience difficulties in the concept of numbers in recognizing number symbols and sorting numbers. The ability to classify objects and pattern recognition of children is still low.

From various findings, researchers developed a pop-up book learning media that is suitable when used in cognitive learning for 4-5-year-old children. Respondents think pop-up books will attractive to children. So, children will focus and not bored. The main attraction reason of pop-up books is the variety of attractive page views (Ma, Wei \& Lin, 2014: 91). Furthermore, Songjing (2014: 623) show that pop-up books are an invaluable source for multimodal discourse analysis because they are not only a means of entertainment for young readers but the main means of literacy, literature and social values. Ramos \& Ramos (2014: 9) show that the diversity of reading in pop-ups is possible to reinforce the notion 
of complexity. More than just a text container, popup books are material objects, with form and language, where existing moving elements and the possibility to describe support have contributed to changing both production and reading practices. In pop-up books, support not only has text but becomes a communicative space (Sarlatto, 2017: 89)

In addition, respondents showed that with the pop-up books, children will motivate in learning. Ray and Smith (2010) showed that using children's books attracts to encourage learners' persistence and motivational behavior related to goals. The motivational potential of children's books in mathematics learning is how books can generate emotional connections to students involves them at various levels (Heuvel and Boogaard, 2008).

In planning, research and development include: (1) determining the material and indicators according to the stage of child development, (2) determining the theme of Pop-Up Books proper to the child's interests, (3) has a pop-up technique proper for the book, (4) decide the image that matches the theme and color suitable for the characteristics of children aged 4-5 years, (5) decide the material to use in a pop-up.

After completing the plan, the next is Product Development. At the development stage, the first step in developing the product was compiling content Pop-Up Books. Pop-up book material about cognitive abilities divided into 3 series has introduced the concept of numbers, classification and pattern recognition. Of these three materials are more inclined to cognitive development in the early mathematics. There are advantages to involving children in the mathematical experience, the knowledge of preschoolers about mathematics can be used to predict the success in elementary school and even high school (Clements \& Sarama, 2011: 968). Furthermore, Lyons \& Ansari (2015: 93) show that numerical and mathematical skills are important predictors of academic success. In addition, the ability to recognize the concept of pattern is very important for children because pattern activities become the center of mathematics. Preschoolers have involved as early algebraic thinking (Johnson, Fyfe, McLean, and McEldoon (2013: 377).

Material experts and media experts conducted Validity testing to test the feasibility of the product before being used in the field. Validation from material experts received an average score of 3.30 which was in the very valid category. Suggestion from material experts that is replacing images and letters in small size to be larger so all children can see them. Setiautami (2011: 316) showed that easyto-read text sizes range from 14 to 24 points depending on the type and age of readers and leading 4 to 6 points. Furthermore, Nurgiyantoro (2016: 93) showed that the size of the letters in children's reading books influenced children's motivation. Large letters will give a better sensory impression and make it easier to remember.

Advice from media experts makes pop-Up Books cover look more interesting. In addition, combinations of colors on cover should use a bright and contrasting color to attract more children's attention. The color choice must adjust to the colors children see. Using natural colors can increase child realism (Smaldino et al., 2011: 76). The next suggestion is to make corners of book curved to be safe for children and not harmful to children. Another suggestion is to create a guidebook to help cognitive stimulation media based on Pop-Up Books.

After being declared feasible by material and media experts, the next step is Preliminary field testing and the main field testing as a product feasibility test. In the preliminary field testing, assess the teacher's response to the content and presentation components received mean scores of 3.32 and 3.33. While for the overall assessment, cognitive stimulation media based on Pop-Up Books received an average score of 3.33. Besides getting an assessment from the teacher, the researcher got data from the child's response. The results of the children's response assessment get an average score of $89 \%$. For a wider field test, assess the teacher's response to the content and presentation components had a mean score of 3.59 and 3.61. While for the overall assessment, cognitive stimulation media based on Pop-Up Books received an average score of 3.60 and included in the "very good" category. Besides getting an asses data from the child's response. The results of the child's response assessment received an average score of $98.6 \%$.

From these results, it can see that material content form in Preliminary Field Test and main Field Test included in a great category. According to the teacher, the material in the pop-up book learning media in accordance with a cognitive development of children aged 4-5 years. Ma et al. (2014: 87) show that picture books designed for children must fulfill the nature of children and have characteristics relevant to language development, cognitive 
involvement, and artistic thinking, pleasure, and to increase the interest and attention of users.

In the presentation form of the two trials included in the excellent category. Display of cover containing various images of transportation tools attracts children's interest. In addition, the contents of the book from the pop-up book media comprising various models of transportation tools make children more enthusiastic in learning. The bright color display is the main attraction of pop-up media book. Pop-up book learning media have communicative, interactive, interesting, and informative properties so the target can receive the message (Aisyah and Fauzi, 2012: 83). Together with these children's books spread an idea that an object can become a book and toy at the same time so that the interest in learning increases (Mosca Bonsignore, 2011).

Children's responses to cognitive learning using pop-up books are in the very good category. Children are very enthusiastic to learn to use pop-up books. They revealed that with pop-up media the book is easier to learn. The curiosity of children increases and children become more active in learning. According to them, various models of transportation tools in the pop-up book are great and interesting. Valerie Carroll (2015: 39) showed that children like pop-up books because they like anticipation; they want to see what's under the fold. Based on the results above the learning media of pop-up books are feasible for improving cognitive abilities of children aged 4-5 years.

The final stage of this study is an operational testing. In this trial, researchers conducted an effectiveness test to determine the effect of using cognitive stimulation media based on Pop-Up Books in developing cognitive abilities of children aged 4-5 years. Paired-sample t-test results for cognitive abilities scores before and after using cognitive stimulation media based on Pop-Up Books have a significant value of $0,000<0.005$. Based on the average value, the posttest value in using cognitive stimulation media based on Pop-Up Books has a higher value than at pretest with an increase of 11.15. These results mean that the posttest and pretest scores have significant differences and show that cognitive stimulation media based on Pop-Up Books is effective for cognitive learning to improve cognitive abilities in children aged 4-5 years in introducing concept numbers, patterns, and classifications.

Hiner (2006: 19) revealed that Pop-up books can teach mathematics to children individually and in groups, besides that for centuries books like this were to help scientific work. Van Oers (2013) acknowledges the potential benefits of children's books to support discourse, especially when discourse can encourage illustrations that support children's thinking about mathematical ideas. Furthermore, Bluemel and Taylor (2012: 4) showed that pop-up books can help students understand reallife situations with symbols or images, and develop students to think critically and creatively.

Dzuanda (2011: 5-6) reveals that Pop-up books can increase knowledge and give shape recognition to objects. Van Dyk (2010: 7) reveals pop-up books can make the learning experience more effective, interactive, and memorable. Using pop-up books can also involve users in a kinetic, through opening books and movable books can also help in combining hands and eyes, action and reaction, and discovery and amazement. From the explanation above, it can be concluded that in the development of children's cognitive abilities using cognitive stimulation media based on Pop-Up Books can improve in cognitive abilities in kindergarten.
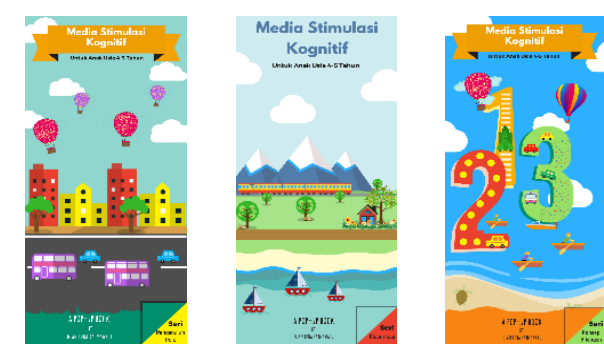

Fig. 2. Cover Pop-Up Book Learning media Conclusion

\section{Conclusion}

Based on the results, the conclusion this research is (1) this research produces a product in the form of a pop-up book entitled "Media Stimulasi Kognitif". The development process in this research adapts 9 out of 10 development stages of Borg and Gall (1983) which include(a) preliminary study, (b) planning, (c) product development, (d) preliminary field testing, (e) revision, (f) main field testing, (g) revision, (h) operational field testing, and (i) final product refinement.,(2) validation result and field testing showed that pop-up book media was feasible to use for children age 4-5 years. score from material expert an media expert 3,30 and 3,42 in very feasible criteria with revisions, while the score from teacher response in preliminary field testing and 
main field testing 3,33 and 3,60 in very feasible criteria with revisions. students' responses result showed $89 \%$ and $98,06 \%$ with very good criteria, and (3) based on the media effectiveness test result, after using pop-up book media, there was improve students' learning outcomes with the gain value from pretest to posttest 11,15. In addition, the results of the paired-sample t-test for cognitive ability before and after using cognitive stimulation media based on Pop-Up Books got a significance value of $0.000<0.005$ which showed that Ha was accepted. So, it can be concluded that the developing pop-up book learning media is effective to improve cognitive ability in children aged 4-5 years.

\section{REFERENCES}

[1] Alborghetti, C. (2013). Dall'ABC a Harry Potter: storia della letteratura inglese per l'infanzia e la gioventù. L'ANALISI LINGUISTICA E LETTERARIA, 20(A), 295295.

[2] Asiyah, N., Fauzi, M., Produk, J. D., \& Kreatif, I. (2012). Perancangan Buku Pop Up Sebagai Media Pendidikan di Organisasi WwfIndonesia. jurnal pendidikan, Fakultas Desain dan Industri Kreatif, Universitas Esa Unggul Jakarta.

[3] Carroll, V. (2015). Preschool Storytime in Auckland's public libraries: A qualitative study of book selection practices.

[4] Clements, D.H \& Sarama, J. (2011). Early childhood mathematics intervention. Science, 333, 968-970.

[5] Duncan, G. J., Dowsett, C. J., Claessens, A., Magnuson, K., Huston, A. C., Klebanov, P., Pagani, L.S., Feinstein, L., Engel, M., BrooksGunn, J. and Sexton, H. (2007). School readiness and later achievement. Developmental psychology, 43(6), 1428-1446.

[6] Dzuanda. (2011). Design Pop-up Child Book Puppet Figures Series:Gatotkaca. Jurnal Library ITS Undergraduate.

[7] Heuvel-Panhuizen, M. V. D., \& Boogaard, S. V. D. (2008). Picture books as an impetus for kindergartners' mathematical thinking. Mathematical Thinking and Learning, 10(4), 341-373.

[8] Hiner, M. (2006). Paper Enginering for Pop-Up Book and Cards. London.

[9] Jamaris, M. (2014). Kesulitan belajar: perspektif, asesmen, penanggulangannya. Bogor: Ghalia Indonesia.

[10] Johnson, B.R., Fyfe, E.R., McLean, L.E., \& McEldoon, K.L. (2013). Emerging understanding of patterning in 4 year olds. Journal Of Cognition And Development, 14(3):375-395.

[11] Kemdikbud, B. (2011). Survei internasional TIMSS. Litbang Kemdikbud [online]. Tersedia: http://www. litbang. kemdikbud. go. id.[ (accessed 16 April 2018].

[12] Lyons, I. M., \& Ansari, D. (2015). Foundations of children's numerical and mathematical skills: the roles of symbolic and nonsymbolic representations of numerical magnitude. In Advances in child development and behavior (Vol. 48, pp. 93-116). JAI.

[13] Ma, M. Y., Wei, C. C., \& Lin, Y. C. (2014). An Attractiveness Evaluation of Picture Books Based on Children's Perspectives. In UMAP Workshops.

[14] Merkley, R., \& Ansari, D. (2016). Why numerical symbols count in the development of mathematical skills: Evidence from brain and behavior. Current Opinion in Behavioral Sciences, 10, 14-20.

[15] Merkley, R., \& Ansari, D. (2016). Why numerical symbols count in the development of mathematical skills: Evidence from brain and behavior. Current Opinion in Behavioral Sciences, 10, 14-20.

[16] Mulligan, J. T., \& Mitchelmore, M. C. (2009). Awareness of pattern and structure in early mathematical development. Mathematics Education Research Journal, 21(2), 33-49.

[17] Murphy, N. A., \& Hall, J. A. (2011). Intelligence and interpersonal sensitivity: A meta-analysis. Intelligence, 39(1), 54-63.

[18] National Mathematics Advisory Panel. (2008). Foundations for success: The final report of the National Mathematics Advisory Panel. US Department of Education.

[19] Nurgiyantoro, Burhan. 2016. Sastra Anak. Yogyakarta:Gadjah Mada University Press.

[20] Piotrowski, J. T., \& Valkenburg, P. M. (2015). Finding orchids in a field of dandelions: Understanding children's differential susceptibility to media effects. American Behavioral Scientist, 59(14), 1776-1789

[21] Ramos, R., \& Ramos, A. M. (2014). Cruce de lecturas y ecoalfabetización en libros pop-up para la infancia. Ocnos: Revista de estudios sobre lectura, (12), 7-24.

[22] Ruiz, C. R., Le, S. N., Yu, J., \& Low, K. L. (2014, May). Multi- style paper pop- up designs from 3D models. In Computer Graphics Forum (Vol. 33, No. 2, pp. 487-496).

[23] Sarlatto, M. (2016). Paper engineers and mechanical devices of movable books of the 19th and 20th centuries. JLIS. it, 7(1), 89-112.

[24] Setiautami, D. (2011). Eksperimen tipografi dalam visual untuk anak, Jurnal Humaniora, 2(1), 311-317. Jakarta: Desain Komunikasi Visual Fakultas KOmunikasi dan multimedia, Universitas Bina Nusantara.

[25] Smaldino, Sharon E.; Deborah L. Lowther; dan James D. Russell. 2011. Intructional Technology and Media For Learning (9nd Edition). Diterjemahkan oleh Arif Rahman. Jakarta: Kencana Prenada Media Group.

[26] Smith, C., \& Ray, K. (2010). The Kindergarten Child: What Teachers and Administrators Need to Know to Promote Academic Success in all Children. Early Childhood Education, 38(1), 14. 
[27] Songjing, Chen (2014) Reading visual narratives: image analysis of children's picture books, Social Semiotics, 24:5, 623-627, DOI: $10.1080 / 10350330.2014 .950010$

[28] Sugiyono. 2015. Metode Penelitian Pendidikan (Pendekatan Kuantitatif,. Kualitatif danR\&D). Penerbit CV. Alfabeta: Bandung.
[29] Van Dyk, S. (2010). Paper Enginering. Washington DC: Smithsonian Institution Libraries.

[30] Van Oers, B. (2013). Learning mathematics as a meaningful activity. In Theories of mathematical learning (pp. 103-126). Routledge 